\title{
Time and Place Calibration of the Hargreaves Equation for Estimating Monthly Reference Evapotranspiration under Different Climatic Conditions
}

\author{
Houshang Ghamarnia (Corresponding author) \\ Department of Irrigation and Water Resources Engineering, Faculty of Agriculture, Razi University \\ P.O. Box: 1158 , post code: 6715685438 , Kermanshah, Iran
}

Tel: 98-831-832-3727 E-mail: hghamarnia@razi.ac.ir; hghamarnia@yahoo.co.uk

Vahid Rezvani

Department of Irrigation and Water Resource Engineering, College of Agriculture

Kurdistan University, Sanandaj, Iran

E-mail: rezvani.vahid@gmail.com

Erfan Khodaei

Department of Irrigation and Water Resources Engineering, Faculty of Agriculture

Razi University, Kermanshah, Iran

E-mail: Erfan.khodaei@gmail.com

Hossein Mirzaei

Department of Irrigation and Water Resources Engineering, Faculty of Agriculture

Razi University, Kermanshah, Iran

E-mail: arshia812003@yahoo.com

Received: July 27, 2011

doi:10.5539/jas.v4n3p111
Accepted: August 29, $2011 \quad$ Online Published: December 29, 2011

URL: http://dx.doi.org/10.5539/jas.v4n3p111

\begin{abstract}
The standardized FAO-56 Penman-Monteith (PM) equation requires a great number of input parameters that are difficult to record. The Hargreaves method is another approach. It has high accuracy, while it requires fewer input parameters. In the present study, the Hargreaves-Samani method was calibrated by the PM equation under different climate conditions, in the western Iran. Different correction coefficients were used for each station under study instead of the constant coefficient 0.0023 in the Hargreaves equation based on monthly and annual scales. The corrected coefficients obtained for different regions can be used to estimate ETo for the PM method under the same climates where reliable data are available. The results also showed that as a larger study area with more weather stations is used and a larger amount of data is obtained, the coefficient of 0.0023 in the Hargreaves equation does not need further corrections for local calibration purposes.
\end{abstract}

Keywords: Reference evapotranspiration, FAO-56 Penman -Monteith, Hargreaves method

\section{Introduction}

The estimation of evapotranspiration is the first and the most important step towards designing, planning and managing different irrigation networks, water distribution systems, water application, calculation of lake surface evaporation losses, implementation of hydrological and agro-hydrological models, environmental studies, water balance, and water management practices (Landras et al, 2008). In semiarid climates where water resources are 
limited and seriously overexploited, precise estimation of crop water requirements is needed for effective management and planning of available water resources (Jabloun and Sahli, 2008).

The different methods applied to estimate evapotranspiration are categorized into two main groups, namely direct and indirect, or computational methods (Alizadeh and Kamali, 2007). The simplest tool to determine evapotranspiration on a small-scale is the lysimetric method. A lysimeter is a tank of a given size that is embedded in soil and water, and its input and output values are measurable (Alizadeh and Kamali, 2007). By using different climate factors in an indirect method, the potential evapotranspiration is calculated, and then by considering different crop coefficients at different crop growth stages, the desired plant evapotranspiration can be calculated (Allen et al, 1998; Savana and Frenken, 2002; Alizadeh and Kamali, 2007).

Reference crop evapotranspiration is generally a reflection of climate effects. A surface evapotranspiration with no water shortages is called a "reference plant evapotranspiration". The reference level is a hypothetical grass reference crop with a height of $0.12 \mathrm{~m}$ and a surface resistance of $70 \mathrm{~m} / \mathrm{sec}$ with reflection coefficient of 0.23 . No lack of water in soil should exist under such circumstances. A similar reference definition for alfalfa with a height of $20 \mathrm{~cm}$ has also been defined (Allen et al, 1998; Alizadeh, 2006; Alizadeh and Kamali, 2007; Trajkovic and Kolakovic, 2009).

The Penman-Monteith method proposed by Allen et al. (1998) as a standardized method needs different climatological data such as relative humidity, air temperature, solar radiation, and wind speed. However, at many weather stations around the world, especially in developing countries such as Iran, not all the required parameters can be measured; hence, an alternative method should be used to estimate reference evapotranspiration with higher accuracy and requiring fewer input parameters. Allen et al. (1998) suggested that should insufficient data be available to resolve the Penman-Monteith equation, the Hargreavess-Samani equation (Hargreaves et al., 1985) can be used instead.

A number of studies have been performed to compare the Penman-Monteith and the Hargreavess-Samani approaches. The Hargreaves equation was used to estimate monthly ETo in the Bajgah region in Fars province, Iran, by Fooladmand and Spaskhah (2005). They reported that during different months of the year, different coefficients should be used instead of the 0.0023 value in the Hargreaves equation. The results obtained with the Hargreaves model were reported to be satisfactory in computing weekly or monthly reference evapotranspiration (Hargreaves and Allen 2003). Martinez-Cob and Tejero-Juste (2004) and Gavilan et al., (2006) suggested that the Hargreavess-Samani method needs specific local calibration to achieve an acceptable performance.

Rahimi Khoob (2008) compared the Penman-Monteith and Hargreaves methods for reference evapotranspiration calculation. For this purpose, data from 12 weather stations located across the Khuzestan plain (southwest Iran) were selected to calculate reference evapotranspiration. He reported that the Hargreavess-Samani method gave significantly higher or lower results than those of the Penman-Monteith method. Kisi (2008) compared the Hargreaves-Samani and Penman-Monteith methods in Los Angeles, USA. He concluded that the calibrated Hargreaves-Samani method is the best approach to estimate evapotranspiration.

Landras et al., (2008) compared various equations for reference evapotranspiration using the Penman-Monteith method for a study area in the northern part of Spain. They reported that the Hargreaves-Samani method had the weakest performance, with a $32.2 \%$ overestimation. Sentelhas et al., (2010) examined different reference evapotranspiration methods in Ontario, Canada. They showed that by considering the amount of available weather data, the Hargreaves-Samani method can be a good alternative to the Penman-Monteith method. Saghravani, et al., (2009) suggested that if the Hargreaves method was used to study a region in the absence of sunshine hours, humidity and wind-speed data, corrections were needed to obtain results that were as reliable and accurate as those obtained with the Penman-Monteith method.

Sabziparvar and Tabari (2010) evaluated the performance of the Makkink, Priestley-Taylor, and Hargreaves models compared to that of the Penman-Monteith FAO-56 method for arid and semiarid regions in northeastern Iran. They reported that the Hargreaves model had the best performance in estimating monthly ETo values. Moreover, in different parts of Iran, the total number of weather stations is too small for the extent of the country, and the analogue instruments used at most of the existing stations do not record all of the necessary meteorological parameters because of lack of proper facilities and poor management. Therefore, it is not possible to estimate reference evapotranspiration based on the Penman-Monteith method because of insufficient data. At most stations, only maximum and minimum air temperatures are recorded, and according to Allen et al. (1998), the Hargreaves model is recommended for computation of reference evapotranspiration when only maximum and minimum air temperature data are available. 
Correct reference evapotranspiration and crop water requirement computations are very important for dam operation and design of irrigation and drainage schemes. Also, the western parts of Iran play a key role in producing agricultural commodities, and a large number of dam construction schemes and irrigation and drainage projects are under study or in progress in these areas. The main objective of the present study was to determine the correction coefficients for each station based on a monthly scale instead of the 0.0023 coefficient of the Hargreaves equation for semi-arid regions in west Iran, for which only maximum and minimum air temperature were recorded and for which comprehensive measurements of meteorological data were unavailable.

\section{Materials and Methods}

The study area is located in west Iran at $32^{\circ} 06^{\prime}$ to $36^{\circ} 33^{\prime} \mathrm{N}$ and $45^{\circ} 24^{\prime}$ to $50^{\circ} 02^{\prime} \mathrm{E}$. The region extends over five provinces, Kermanshah, Lorestan, Ilam, Kurdistan, and Hamadan, covering an area of approximately 106,508 square kilometers. The average annual rainfall is about $480 \mathrm{~mm}$, and based on the Thornthwaite classification, the regional climates are dry sub-humid, moist sub-humid, semi-arid, and humid. Figure (1) and Table (1) show the spatial distributions, meteorological data and climate information of 24 selected stations. As shown in Table (1), this area is dominated by dry sub-humid climate.

The data included maximum temperature (Tmax), minimum temperature (Tmin), dew point temperature (Tdew), maximum relative humidity (RHmax), minimum relative humidity (RHmin), average relative humidity (RHmean), wind speed (U), and sunshine hours (n).

To calculate wind speed at two-meter height, the equation proposed by Allen et al. (1998) was:

$$
U_{2}=\frac{4.87 \cdot U_{10}}{\ln (67.8 \cdot 10-5.42)}
$$

where $\mathrm{U}_{2}$ is the average 24-hour wind speed at a height of $2 \mathrm{~m}$ and $\mathrm{U}_{10}$ is average 24-hour wind speed at a height of $10 \mathrm{~m}$.

The solar radiation was calculated by using the following formula:

$$
R_{s}=\left(0.25+0.5 \frac{n}{N}\right) \cdot R_{a}
$$

where $R_{s}$ is the net solar radiation $\left(M J ~ m^{-2} d a y^{-1}\right.$ ), $N$ is the maximum possible sunshine hours $(h), n$ is the number of actual sunshine hours $(\mathrm{h})$, and $\mathrm{R}_{\mathrm{a}}$ is the extraterrestrial radiation $\left(\mathrm{MJ} \mathrm{m}^{-2} \mathrm{day}^{-1}\right)$.

\subsection{ET Reference Methods}

Allen et al., (1998) proposed the FAO-Penman-Monteith method as a standard method to estimate, evaluate and calibrate the ET reference value. This method has been used by many researchers (Gavilan et al, 2006; Rahimikhoob, 2008; Fooladmand and Haghighat, 2007 Noori mohammadieh et al, 2009; Sabziparvar and Tabari, 2010), and the equation can be rewritten following Allen et al (1998):

$$
\text { ETo }=\frac{0.408 \Delta\left(R_{n}-G\right)+\gamma \frac{900}{T+273} v 2\left(e_{s}-e_{a}\right)}{\Delta+\gamma(1+0.34 v 2)}
$$

where $\mathrm{ET}_{\mathrm{o}}$ is the reference evapotranspiration $\left(\mathrm{mm} \mathrm{day}^{-1}\right), \mathrm{R}_{\mathrm{n}}, \mathrm{G}$, and $\mathrm{T}$ are net radiation values at the crop surface $\left(\mathrm{MJ} \mathrm{m}^{-2} \mathrm{day}^{-1}\right)$, soil heat flux density $\left(\mathrm{MJ} \mathrm{m}^{-2}\right.$ day $\left.^{-1}\right)$, and mean daily air temperature at $2 \mathrm{~m}$ height $\left({ }^{\circ} \mathrm{C}\right)$, respectively. Also, $u_{2}, e_{s} e_{a},\left(e_{s}-e_{a}\right), \Delta$, and $\gamma$ are wind speed at $2 \mathrm{~m}$ height $\left(\mathrm{m} \mathrm{s}^{-1}\right)$, saturation vapor pressure $(\mathrm{kPa})$, actual vapor pressure $(\mathrm{kPa})$, saturation vapor pressure deficit $(\mathrm{kPa})$, slope of the saturation vapor pressure curve $\left(\mathrm{kPa} /{ }^{\circ} \mathrm{C}\right)$, and psychrometric constant $\left(\mathrm{kPa} /{ }^{\circ} \mathrm{C}\right)$, respectively.

The Hargreaves equation (Hargreaves and Samani, 1985) can be written as follows:

$$
\text { ETo }=0.0023\left(T_{\text {mean }}+17.8\right)\left(T_{\max }-T_{\min }\right) 0.5 R_{a}
$$

where Tmean, Tmax and Tmin are mean, maximum and minimum temperatures $\left({ }^{\circ} \mathrm{C}\right)$, respectively, and $R a$ is extraterrestrial radiation ( $\mathrm{MJ} \mathrm{m}^{-2} \mathrm{day}^{-1}$ ) converted to equivalent evaporation in $\mathrm{mm}$ day ${ }^{-1}$ with a factor of 0.408 .

The climate of each region was determined by using the Thorontwhiet model as below (Shahid et al., 2005): 


$$
P E I=\sum_{n=1}^{12} 115\left(\frac{P}{T-10}\right)^{10 / 9}
$$

where $\mathrm{P}$ is monthly precipitation (inch), $\mathrm{T}$ is average monthly temperature (Fahrenheit), and $\mathrm{n}$ is the number of months $(\mathrm{n}=12)$.

\subsection{Calibration}

In order to calibrate the Hargreavess-Samani equation using monthly data, the Penman-Monteith method was used as follows:

$$
E T_{0-P M}=\lambda \times E T_{0-H \text { arg reaves }}
$$

where $\lambda$ is the slope of the correlation of evapotranspiration by the Hargreavess-Samani and Penman Monteith methods. Finally, the Hargreaves equation for each region and each month of the year was corrected:

$$
C=\lambda \times 0.0023
$$

where $\mathrm{C}$ is the monthly corrected value for each station.

\subsection{Model comparison}

ETo estimates by the PM and HG models were compared using simple error analysis and the linear regression method. Both methods were compared before and after adjustments were applied. For each location, the following parameters were also calculated (Willmott, 1982): root mean square error (RMSE), mean bias error (MBE), and the ratio of average estimations of ETo (R).

$$
\begin{gathered}
R M S E=\left[\frac{\sum_{i=1}^{n}\left(X_{H \text { arg }}-X_{P M}\right)^{2}}{n}\right]^{1 / 2} \\
M B E=\left[\frac{\sum_{i=1}^{n}\left(X_{H \text { arg }}-X_{P M}\right)}{n}\right] \\
R=\frac{X_{H \text { arg }}}{X_{P M}}
\end{gathered}
$$

where $\mathrm{X}_{\mathrm{Harg}}, \mathrm{X}_{\mathrm{pm}}$, and $\mathrm{n}$ are the evaporation values estimated by the Hargreaves and Penman- Monteith methods and data number, respectively.

\section{Results and discussion}

Monthly ETo values for all the stations were estimated by the FAO-Penman-Monteith (PM) and Hargreavess-Samani (HG) methods, and the results were compared. The monthly and annual slope values $(\lambda)$ for the different stations based on the regression between ET0-Harg and ET0- ${ }_{\text {PM }}$ are shown in Table (2).

Table (3) shows the monthly and annual values of RMSE (Root mean square error). A comparison shows that the lowest monthly RMSE index belonged to the Aleshtar Station, with dry sub-humid climate and with a value of 0.095 in December. The highest RMSE, with a value of 3.132, was recorded at the Baneh Station under a moist sub-humid climate in August. Annually, the highest and lowest RMSE values of 1.946 and 0.334 were at the Baneh and Azna stations, with moist sub-humid and dry sub-humid climates, respectively. The results showed that the RMSE values in warm months were higher than those in cold months of the year, causing differences between evapotranspiration values calculated by the Hargreaves and Penman-Monteith methods. In the warmest months of the year, including May, June, July and August, the differences between ET0-Harg and ET0-pM values were the highest, while in the coldest months of the year, including October, November, December, Janury, Februry, March and April, the differences between ET0-Harg and ET0-PM values were the lowest. 
The MBE (Mean bias error) values for different meteorological stations are shown in Table (4). A comparison of the results showed overestimated (positive) values or underestimated (negative) values for ETo predicted by the Hargreaves and Penman-Monteith methods. The results of the MBE comparison in Table (4) showed that the minimum and maximum values of MBE were obtained at Ravansar Station, with a value of -1.819 in July, and Kouhdasht Station, with a value of +1.546 in August, both under dry sub-humid climates. Negative and positive values of MBA indicate underestimated and overestimated values for the Hargreaves and Penman-Monteith methods, respectively. As Table (4) shows, for annual results, the minimum and maximum values of MBE were obtained at Banah Station, with a value of -1.634 , and Kouhdasht Station, with a value of +0.678 , for moist sub-humid and dry sub-humid climates, respectively.

As presented in Table (5), the monthly and yearly values of the $\mathrm{C}$ coefficients were estimated. For the monthly results, the lowest value of C was 0.0018 for Eslamabad Gharb Station in December, while it was for Kuhdasht Station in August. Both stations were located in dry sub-humid climates. Also, as shown in Table (5), the highest $\mathrm{C}$ value, 0.0042 , was obtained for Banah Station under a moist sub-humid climate in October.

The annual results showed that the lowest and highest $\mathrm{C}$ values were obtained for Kohdasht and Baneh Stationed, 0.0019 and 0.0035 , respectively. Table (5) shows that the annual $\mathrm{C}$ coefficients for each station differ. The lowest $\mathrm{C}$ value was obtained at Dorud Station with a value of 0.00011 in a moist sub-humid climate, while the greatest difference was obtained at Dehloran, west Islamabad, Ilam, Kangavar, Kermanshah, Khoramabad, Kohdasht, Marivan, and Sanandaj Stations, with a value of 0.0003. The climate at the Marivan Station is humid, that of Dehloran is semi-arid, and that of the rest is dry sub-humid.

As Table (5) shows, C coefficients were lower than 0.0023 for Islam Abad Gharb, Kangavar, Khoramabad, Kohdasht, Saghez, and Sanadnaj Stations, all with dry sub humid climate, and Marivan station with humid climate. This implies that the $\mathrm{ET}_{\mathrm{o}}$ values estimated by the Hargreaves method were higher than those by the Penman-Monteith method. For stations with $\mathrm{C}$ coefficient higher than 0.0023 , the $\mathrm{ET}_{\mathrm{o}}$ values estimated by the Hargreaves method were lower than those by Penman-Monteith method. Figures (2) and (3) show the place and time in which $\mathrm{C}$ distribution coefficients were obtained for monthly and annual results at all stations under study.

Different $\mathrm{R}$ index values are shown in Table (6). The indexes show that the ratio of the Hargreaves $\mathrm{ET}_{\mathrm{o}}$ values have been either overestimated or underestimated as compared to those by the Penman-Monteith method. The greatest overestimate was obtained for Kuhdasht Station, 25.2\% in August, while the greatest underestimate was obtained for Banah Station, $45.1 \%$ in October. For annual results, the greatest overestimate, $17.9 \%$, was obtained for Kuhdasht Station, while the greatest underestimate, 34.41\%, was obtained for Banah Station. These differences probably were caused by the higher wind speed of $4.93 \mathrm{~m} / \mathrm{s}$ at Banah Station as compared to the wind speed of $1.75 \mathrm{~m} / \mathrm{s}$ at Kuhdasht Station. The annual results at Nahavand Station estimated by the Hargreaves method equal those estimated by the Penman- Monteith method. Figure (4) shows that for annual results, the Hargreaves $\mathrm{ET}_{\mathrm{o}}$ values were either overestimated or underestimated as compared to the Penman-Monteith method at all stations.

Figure (5) shows the mean monthly ETo values calculated by the PM method along with those estimated by the HG method for all meteorological stations from 1986-2005. The HG method gave a correlation of $\mathrm{R}^{2}=0.861$ and the relationship equation $\mathrm{y}=1.008 \mathrm{x}$. Based on this equation, the value of parameter $\lambda$ was obtained as 1.008 , and the $\mathrm{C}$ value was determined to be 0.0023 using Eq.(6). One can conclude that when the investigation area is more extensive and a larger number of weather stations and available data are used, the coefficient of 0.0023 in the Hargreaves equation does not require any local calibrations. The results of the present study differ from those suggested by Noori Mohammadieh et al. (2009), who reported satisfactory ETo estimations for 18 locations.

Salako (2008) found that the daily means of PM ETo values were significantly correlated with those of the HG method $\left(\mathrm{P}<0.0001, \mathrm{r}^{2}\right.$ from 0.72-0.93) and pan ETo values $\left(\mathrm{P}<0.0001, \mathrm{r}^{2}\right.$ from $\left.0.91-0.93\right)$. He also reported that the regression equations developed for three agroecological zones of Nigeria can be used to estimate PM ETo values for similar climatic zones where data requirements cannot be met but data for the HG or pan method are available.

Jabloun and Sahli (2008) evaluated the Hargreaves equation. They reported that the results obtained from the comparison of ETo daily estimates by the Hargreaves equation with FAO-56 PM, estimates taken as reference throughout different Tunisian locations showed a systematic overestimation at inland sites but that at coastal sites, the Hargreaves equation tended to underestimate ETo values. They suggested that further research would be required to adjust the Hargreaves coefficients to local conditions for obtaining better accuracy. 


\section{Conclusions}

The main objective of this study was to evaluate the Hargreaves temperature-based method to estimate daily ETo values for western semi-arid parts of Iran. Monthly data were used for monthly ETo calculations at all 24 meteorological stations by the Hargreaves and Penman- Monteith methods. For this purpose, the calibration process was based on monthly and yearly data. The calibration results of two ETo estimated methods showed either high or low results at different stations. Finally, for all the selected stations, the monthly and yearly Hargreaves $\mathrm{C}$ coefficients were calculated.

For monthly results, the lowest and highest $\mathrm{C}$ values were 0.0018 and 0.0042 . For annual results, the lowest and highest $\mathrm{C}$ values were 0.0019 and 0.0035 . Finally, at all 24 meteorological stations, $\mathrm{C}$ coefficients were determined. By using corrected $\mathrm{C}$ coefficients and temperature measurements, one can suggest that the values of ETo by the Hargreaves method can be simply obtained.

The overall results also showed that when the study area is larger, more weather stations are used, and reliable data are available, the coefficient of 0.0023 used in the Hargreaves method does not need any corrections for local calibrations and can be applied with confidence.

Moreover, the results indicated that both monthly and yearly means by the Hargreaves method were significantly correlated with those of the Penman-Monteith method at all available recording stations in western Iran; hence, it is possible to predict monthly and yearly ETo values precisely in other areas where the required data for the Penman-Monteith estimations are unavailable and only maximum and minimum air temperatures have been recorded.

\section{References}

Alizadeh, A., \& Kamali, G. (2007). Plants water requirements in Iran. Publication by Imam Reza University, Mashhad, 228.

Alizadeh, A. (2007). Surface Irrigation systems design. Publication by Imam Reza University, Mashhad, 452.

Allen, R. G., Pereira, L.S., Reas, D., \& Smith, M. (1998). Crop Evapotranspiration. FAO Irrigation and Drainage Paper 56, Rome, 300.

Fooladmand, H. R., \& Haghighat, M. (2007). Spatial and temporal calibration of Hargreaves equation for calculating monthly ETo based on Penman-Monteith method. Irrigation and Drainage, 56(4), 439-449.

Fooladmand, H.R., \& Sepaskhah A. R. (2005). Regional calibration of Hargreaves equation in a semiarid region. Iran-Water Recourses Research, 1(2), 1-6. (In persion).

Gavila'n, P., Lorite, I.J., Tornero, S., \& Berengena, J. (2006). Regional calibration of Hargreaves equation for estimating reference ET in a semiarid environment. Agricultural Water Management, 81(3), 257-281.

Hargreaves, G.H., \& Samani, Z.A. (1985). Reference crop evapotranspiration from ambient air temperature, Paper No. 85-2517. American society of agricultural engineers. Chicago, IL.

Hargreaves, G.H., \& Allen, R.G. (2003). History and evaluation of Hargreaves evapotranspiration equation. Journal of Irrigation and Drainage Engineering, 129(1), 53-63.

Jabloun, M., \& Sahli, A. (2008). Evaluation of FAO-56 methodology for estimating reference evapotranspiration using limited climatic data Application to Tunisia. Agricultural Water Management, 95(6), 707 - 715.

Kisi, O. (2008). The potential of different ANN techniques in evapotranspiration modeling. Hydrological Processes, 22, 2449-2460.

Landeras, G., Ortiz-Barredo, A., \& Lopez, J. (2008). Comparison of artificial neural network models and empirical and semi-empirical equations for daily reference evapotranspiration estimation in the Basque Country (Northern Spain). Agricultural Water Management, 95(5), 553-565.

Martinez-Cob, A. \& Tejero-Juste, M. (2004). A wind-based qualitative calibration of the Hargreaves ETo estimation equation in semiarid regions. Agricultural Water Management, 64(3), 251-264.

Noori mohammadieh, M., Mohammadi, M., Helali, J., Nazari, B., \& Sohrabi, T. (2009). Evaluation of Hargreaves equation for calculating daily ETo (Case study: North West of Iran). Advances in Natural and Applied Sciences, 3(2), 273-278.

Rahimi Khoob, A. (2008a). Artificial neural network estimation of reference evapotranspiration from pan evaporation in a semi-arid environment. Irrigation Sciences, 27, 35-39. 
Rahimi Khoob, A. (2008b). Comparative study of Hargreaves's and artificial neural network's methodologies in estimating reference evapotranspiration in a semiarid environment. Irrigation Sciences, 26, 253-259.

Sabziparvar, A. A., \& Tabari, H. (2010). Regional Estimation of Reference Evapotranspiration in Arid and Semiarid Regions. Journal of Irrigation and Drainage Engineering, 136(10), 724-731.

Saghravani S. R., Mustapha, S., Ibrahim, S., \& Randjbaran, E. (2009). Comparison of Daily and Monthly Results of Three Evapotranspiration Models in Tropical Zone: A Case Study. American Journal of Environmental Sciences, 5(6), 698-705.

Salako, F. K. (2008). Estimation of Evapotranspiration with FAO-56 Penman-Monteith equation for three Agroecological zones of Nigeria. ASSET, An International Journal, 8(2), 134-149.

Savana, A. P., \& Frenken, K. (2002). Crop water requirements and irrigation scheduling. FAO irrigation manual, module 4, Harare, 132.

Sentelhas, P. C., Gillespie, T. J., \& Santos, E. A. (2010). Evaluation of FAO Penman -Monteith and alternative methods for estimating reference evapotranspiration with missing data in Southern Ontario, Canada. Agricultural Water Management, 97(5), 635-644.

Shahid, S., Chen, X., \& Hazarika, M. K. (2005). Assessing aridity in Bangladesh using Geographic Information System. GIS Development, 9(12), 40-43.

Trajkovic, S., \& Kolakovic, S. (2009). Evaluation of reference evapotranspiration equations under humid conditions. Water Resources Management, 23(14), 3057-3067.

Willmott, C. J. (1982). Some Comments on the Evaluation of Model Performance, Bulletin of the American Meteorological Society, 63(11), 1309-1313.

Table 1. Localization, meteorological data and climate of the 24 selected stations in this study

\begin{tabular}{|c|c|c|c|c|c|c|c|c|c|c|c|c|}
\hline Station name & Latitude & Longitude & Elevation & Record & Precipitation & $\mathrm{T}_{\max }$ & $\mathrm{T}_{\min }$ & $\mathrm{T}_{\text {dew }}$ & $\mathrm{U}_{10}$ & $\mathrm{RH}_{\text {mean }}$ & $\mathrm{n}$ & Climate $^{* *}$ \\
\hline & (degree) $^{*}$ & (degree) $^{*}$ & (m) & Period & $(\mathrm{mm})$ & $\left({ }^{\circ} \mathrm{C}\right)$ & $\left({ }^{\circ} \mathrm{C}\right)$ & $\left({ }^{\circ} \mathrm{C}\right)$ & (Knot) & $(\%)$ & (hr) & \\
\hline Aleshtar & $33^{\circ} 49^{\prime}$ & $48^{\circ} 15^{\prime}$ & 1567.2 & $2000-2005$ & 497.25 & 22.1 & 3.0 & 0.9 & 4.8 & 49.6 & 260.4 & Dry sub-humid \\
\hline Aligoodarz & $33^{\circ} 24^{\prime}$ & $49^{\circ} 42^{\prime}$ & 2022 & 1986-2005 & 398.82 & 19.0 & 5.6 & -2.9 & 7.1 & 40.2 & 266.3 & Dry sub-humid \\
\hline Azna & $33^{\circ} 27^{\prime}$ & $49^{\circ} 25^{\prime}$ & 1871.9 & 2001-2005 & 438.58 & 20.4 & 4.5 & -0.3 & 4.3 & 46 & 262.7 & Dry sub-humid \\
\hline Baneh & $36^{\circ} 00^{\prime}$ & $45^{\circ} 54^{\prime}$ & 1600 & $2000-2005$ & 708 & 18.6 & 8.7 & -0.1 & 9.6 & 44.3 & 240.1 & Moist sub-humid \\
\hline Bijar & $35^{\circ} 53^{\prime}$ & $47^{\circ} 37^{\prime}$ & 1883.4 & $1987-2005$ & 339.9 & 16.5 & 5.3 & -1.7 & 8 & 47.8 & 250.6 & Dry sub-humid \\
\hline Broujerd & $33^{\circ} 55^{\prime}$ & $48^{\circ} 45^{\prime}$ & 1629 & 1993-2005 & 463.6 & 21.4 & 8.2 & -1 & 6.9 & 42 & 259 & Dry sub-humid \\
\hline Dehloran & $32^{\circ} 41^{\prime}$ & $47^{\circ} 16^{\prime}$ & 232 & 1996-2005 & 288.7 & 32.3 & 20.2 & 8.6 & 4.3 & 38.2 & 265.1 & Semi-arid \\
\hline Doroud & $33^{\circ} 29^{\prime}$ & $49^{\circ} 04^{\prime}$ & 1526.7 & 2000-2005 & 679.5 & 22.4 & 9.9 & -1.4 & 5.7 & 37.7 & 263 & Moist sub-humid \\
\hline Eslamabad Gharb & $34^{\circ} 07^{\prime}$ & $46^{\circ} 28^{\prime}$ & 1348.8 & $1987-2005$ & 483.6 & 22.1 & 5.1 & 1.1 & 3.2 & 50.4 & 255.7 & Dry sub-humid \\
\hline Ghorveh & $35^{\circ} 10^{\prime}$ & $47^{\circ} 48^{\prime}$ & 1906 & $1992-2005$ & 341.4 & 17.4 & 5.4 & -1.8 & 6.3 & 45.3 & 252.9 & Dry sub-humid \\
\hline Ilam & $33^{\circ} 38^{\prime}$ & $46^{\circ} 26^{\prime}$ & 1337 & 1995-2005 & 554.2 & 22.7 & 11.6 & 0.7 & 4.7 & 40.6 & 264.6 & Dry sub-humid \\
\hline Kangavar & $34^{\circ} 30^{\prime}$ & $47^{\circ} 59^{\prime}$ & 1468 & $1987-2005$ & 400.2 & 21.3 & 4.3 & 1 & 3.4 & 51.6 & 253.5 & Dry sub-humid \\
\hline Kermanshah & $34^{\circ} 21^{\prime}$ & $47^{\circ} 09^{\prime}$ & 1318.6 & 1983-2005 & 433.3 & 23.2 & 6.5 & 0.3 & 4.3 & 45.3 & 243.3 & Dry sub-humid \\
\hline Khorramabad & $33^{\circ} 26^{\prime}$ & $48^{\circ} 17^{\prime}$ & 1147.8 & $1982-2005$ & 491.9 & 24.7 & 8 & 2.4 & 3.3 & 48.1 & 249.9 & Dry sub-humid \\
\hline Kouhdasht & $33^{\circ} 32^{\prime}$ & $47^{\circ} 38^{\prime}$ & 1199.8 & 1998-2005 & 391.7 & 24.8 & 6.9 & 2.7 & 3.4 & 47.3 & 270.8 & Dry sub-humid \\
\hline Malayer & $34^{\circ} 15^{\prime}$ & $48^{\circ} 51^{\prime}$ & 1777.8 & 1994-2005 & 305.1 & 20.6 & 6.2 & -0.3 & 5.2 & 45.7 & 260.5 & Dry sub-humid \\
\hline Marivan & $35^{\circ} 31^{\prime}$ & $46^{\circ} 12^{\prime}$ & 1286.8 & 1994-2005 & 957 & 20.9 & 5.2 & 2.2 & 3.7 & 53.9 & 247.9 & Humid \\
\hline Nahavand & $34^{\circ} 09^{\prime}$ & $48^{\circ} 25^{\prime}$ & 1680.9 & $1997-2005$ & 368.4 & 21 & 6.7 & 1 & 4.6 & 44.9 & 271.7 & Dry sub-humid \\
\hline Noorabad & $34^{\circ} 03^{\prime}$ & $48^{\circ} 00^{\prime}$ & 1859.1 & $2001-2005$ & 478.3 & 18.9 & 4.8 & -1.7 & 7.8 & 45.2 & 256 & Dry sub-humid \\
\hline Poldokhtar & $33^{\circ} 09^{\prime}$ & $47^{\circ} 43^{\prime}$ & 713.5 & 1999-2005 & 372.2 & 29 & 16.6 & 3.5 & 5.6 & 36.3 & 266 & Semi-arid \\
\hline Ravansar & $34^{\circ} 43^{\prime}$ & $46^{\circ} 39^{\prime}$ & 1379.7 & 1991-2005 & 537.5 & 21.6 & 8.1 & -0.2 & 5.5 & 45.3 & 253.8 & Dry sub-humid \\
\hline Saghez & $36^{\circ} 15^{\prime}$ & $46^{\circ} 16^{\prime}$ & 1522.8 & 1983-2005 & 482.4 & 18.8 & 2.9 & 0.5 & 3.8 & 54.2 & 240.8 & Dry sub-humid \\
\hline Sanandaj & $35^{\circ} 20^{\prime}$ & $47^{\circ} 00^{\prime}$ & 1373.4 & $1982-2005$ & 441.6 & 21.6 & 5.5 & 0.3 & 3.6 & 48.9 & 237.7 & Dry sub-humid \\
\hline Zarineh Obato & $36^{\circ} 04^{\prime}$ & $46^{\circ} 55^{\prime}$ & 2142.6 & $1991-2005$ & 409.5 & 14 & 1.7 & -2.5 & 7.3 & 54.3 & 255 & Dry sub-humid \\
\hline
\end{tabular}

*Degrees, minutes; $\mathrm{T}_{\min }=$ minimum air temperature, $\mathrm{T}_{\max }=$ maximum air temperature, $\mathrm{T}_{\mathrm{dew}}=$ dew point temperature, $\mathrm{U}_{10}=$ wind speed at $10 \mathrm{~m}$ height, $\mathrm{RH}_{\text {mean }}=$ mean relative humidity, $\mathrm{n}=$ mean monthly total sunshine hours. ${ }^{* *}$ The classification of the climatic regions based on Thornthwaite's method. 
Table 2. The value slope of $(\lambda)$ based on regression between ET0-Harg and ET0-PM

\begin{tabular}{|c|c|c|c|c|c|c|c|c|c|c|c|c|c|}
\hline Station & JAN & FEB & MAR & APR & MAY & JUNE & JULY & AUG & SEP & OCT & NOV & DEC & Yearly \\
\hline Aleshtar & 0.907 & 0.990 & 1.027 & 0.928 & 0.915 & 0.890 & 0.920 & 0.909 & 0.981 & 1.073 & 1.025 & 0.935 & 0.932 \\
\hline Aligoodarz & 1.418 & 1.326 & 1.276 & 1.190 & 1.188 & 1.157 & 1.188 & 1.265 & 1.338 & 1.466 & 1.460 & 1.490 & 1.235 \\
\hline Azna & 0.947 & 1.101 & 1.027 & 1.021 & 1.009 & 0.943 & 0.961 & 0.960 & 0.972 & 1.128 & 0.999 & 0.944 & 0.979 \\
\hline Baneh & 1.440 & 1.388 & 1.476 & 1.419 & 1.398 & 1.501 & 1.415 & 1.536 & 1.715 & 1.820 & 1.756 & 1.669 & 1.509 \\
\hline Bijar & 1.454 & 1.463 & 1.387 & 1.328 & 1.276 & 1.224 & 1.158 & 1.219 & 1.371 & 1.524 & 1.614 & 1.567 & 1.254 \\
\hline Broujerd & & 1.389 & 1.286 & 1.181 & 1.146 & 1.140 & 1.154 & 1.177 & 1.270 & & 1.487 & 1.512 & 92 \\
\hline Dehloran & 1.002 & 1.074 & 1.060 & 1.040 & 1.015 & 1.065 & 1.036 & 1.021 & 1.065 & 1.089 & 1.107 & 0.995 & 1.044 \\
\hline Doroud & 1.294 & 1.496 & 1.357 & 1.224 & 1.170 & 1.070 & 1.030 & 1.057 & 1.089 & 1.412 & 1.387 & 1.430 & 1.117 \\
\hline Eslamabad Gharb & 0.808 & 0.846 & 0.872 & 0.845 & 0.854 & 0.875 & 0.861 & 0.914 & 0.926 & 0.883 & 0.883 & 0.802 & 0.879 \\
\hline Ghorveh & 1.286 & 1.304 & 1.306 & 1.253 & 1.197 & 1.154 & 1.095 & 1.160 & 1.262 & 1.382 & 1.383 & 1.356 & 1.180 \\
\hline $\mathrm{am}$ & 1.140 & 1.175 & 1.161 & 1.127 & 1.161 & 1.185 & 1.192 & 1.197 & 1.236 & 1.249 & 1.228 & 1.119 & 1.191 \\
\hline Kangavar & 0.895 & 0.953 & 0.962 & 0.891 & 0.874 & 0.851 & 0.812 & 0.814 & 0.871 & 0.927 & 0.899 & 0.878 & 0.850 \\
\hline Kermanshah & 0.970 & 1.038 & 0.996 & 0.945 & 0.914 & 0.922 & 0.909 & 0.938 & 0.959 & 1.004 & 1.017 & 0.980 & 0.935 \\
\hline Khorramabad & 0.830 & 0.931 & 0.899 & 0.814 & 0.837 & 0.836 & 0.826 & 0.843 & 0.871 & 0.923 & 0.857 & 0.841 & 0.850 \\
\hline Kouhdasht & 0.866 & 0.950 & 0.909 & 0.865 & 0.865 & 0.832 & 0.819 & 0.798 & 0.819 & 0.928 & 0.869 & 0.837 & 0.836 \\
\hline Malayer & 1.179 & 1.204 & 1.131 & 1.084 & 1.031 & 1.007 & 0.991 & 0.997 & 1.099 & 1.183 & 1.212 & 1.231 & 1.036 \\
\hline Marivan & 0.861 & 0.907 & 0.934 & 0.904 & 0.8 & 0.904 & 0.881 & 0.872 & 0.974 & 1.011 & 0.934 & 17 & 0.905 \\
\hline & & 1. & 1.165 & & & & 0.9 & 0.946 & 0.969 & & 1.090 & & 0.970 \\
\hline Noorabad & & 1.258 & 1.266 & 1.1 & & 1.178 & 1.140 & 1.191 & 1.269 & 1.480 & 1.439 & 1.291 & 1.199 \\
\hline Poldokhtar & 1.128 & 1.213 & 1.188 & 1.156 & 1.213 & 1.129 & 1.123 & 1.105 & 1.200 & 1.415 & 1.403 & 1.101 & 1.165 \\
\hline Ravansar & 1.056 & 1.097 & 1.056 & 0.993 & 1.035 & 1.150 & 1.254 & 1.246 & 1.210 & 1.247 & 1.181 & 1.000 & 1.177 \\
\hline Saghez & 0.898 & 0.971 & 0.954 & 0.930 & 0.894 & 0.855 & 0.861 & 0.888 & 0.934 & 1.020 & 0.963 & 0.968 & 0.892 \\
\hline Sanandaj & 0.898 & 0.987 & 0.970 & 0.904 & 0.893 & 0.868 & 0.885 & 0.867 & 0.881 & 0.948 & 0.937 & 0.963 & 0.889 \\
\hline Zarineh Obato & 1.293 & 1.265 & 1.228 & 1.178 & 1.181 & 1.166 & 1.115 & 1.178 & 1.343 & 1.437 & 1.377 & 1.374 & 1.189 \\
\hline
\end{tabular}

Table 3. The values of RMSE between ET0-Harg and ET0-PM

\begin{tabular}{|c|c|c|c|c|c|c|c|c|c|c|c|c|c|}
\hline Station & JAN & FEB & MAR & APR & MAY & JUNE & $\overline{\text { JULY }}$ & AUG & SEP & OCT & NOV & DEC & Yearly \\
\hline Aleshtar & 0.142 & 0.154 & 0.291 & 0.384 & 0.499 & 0.815 & 0.714 & 0.682 & 0.623 & 0.537 & 0.150 & 0.095 & 0.489 \\
\hline Aligoodarz & 0.433 & 0.489 & 0.672 & 0.767 & 1.056 & 1.198 & 1.554 & 1.835 & 1.754 & 1.494 & 0.825 & 0.586 & .159 \\
\hline Azna & 0.128 & 0.377 & .253 & 0.228 & 0.300 & 0.494 & 0.491 & 0.309 & 0.350 & 0.492 & 0.134 & & 334 \\
\hline Baneh & 0.349 & 0.422 & 0.980 & 1.294 & 1.722 & 2.862 & 2.575 & 3.132 & 3.026 & 2.121 & & & \\
\hline Bijar & 294 & 0.486 & 0.771 & 1.082 & 1.289 & 1.438 & 1.140 & 1.428 & 1.650 & 1.352 & 0.794 & 0.456 & .101 \\
\hline Brou & 397 & 0.625 & 0.717 & 0.748 & 0.855 & 1.018 & 1.158 & 1.214 & 1.431 & 1.351 & 0.851 & 0.656 & 968 \\
\hline Dehloran & 0.198 & 0.457 & 0.468 & 0.958 & 1.186 & 1.405 & 1.414 & 1.316 & 1.018 & 0.912 & 0.619 & 0.354 & 0.952 \\
\hline Doroud & 0.368 & 0.890 & 1.015 & 0.869 & 0.915 & 0.691 & 0.406 & 0.463 & 0.646 & 1.482 & 0.747 & 0.496 & 0.808 \\
\hline Eslamabad Gharb & 0.239 & 0.268 & 0.358 & 0.662 & 0.864 & 1.058 & 1.237 & 0.817 & 0.605 & 0.548 & 0.362 & 0.290 & 0.684 \\
\hline Ghorveh & 0.239 & 0.387 & 0.637 & 0.844 & 0.962 & 1.037 & 0.782 & 1.027 & 1.246 & 1.089 & 0.576 & 0.371 & 0.826 \\
\hline Ilam & 0.185 & 0.309 & 0.464 & 0.507 & 0.869 & 1.208 & 1.348 & 1.264 & 1.210 & 0.840 & 0.447 & 0.198 & 0.849 \\
\hline Kangavar & 0.156 & 0.179 & 0.270 & 0.482 & 0.785 & 1.167 & 1.492 & 1.463 & 0.722 & 0.458 & 0.289 & 0.221 & 0.799 \\
\hline Kermanshah & 0.184 & 0.176 & 0.248 & 0.313 & 0.585 & 0.755 & 0.858 & 0.579 & 0.498 & 0.285 & 0.247 & 0.128 & 0.467 \\
\hline Khorramabad & 0.356 & 0.322 & 0.469 & 0.916 & 1.195 & 1.619 & 1.816 & 1.490 & 1.181 & 725 & 0.460 & 0.321 & 1.047 \\
\hline Kouhdasht & 0.216 & 0.205 & 0.404 & 0.625 & 0.892 & 1.3 & 1. & 1.5 & 1.185 & 85 & 0 . & 0.302 & \\
\hline & 0.238 & 0.3 & 0.346 & 0.380 & 0.2 & & 0. & & 0.668 & 678 & & 0.384 & \\
\hline Marivan & 0.184 & 0.188 & 0.282 & 0.431 & 0.652 & 0.778 & 1.071 & 1.120 & 0.537 & 0.451 & 0.238 & 0.171 & 0.606 \\
\hline Nahavand & 0.174 & 0.344 & 0.477 & 0.373 & 0.505 & 0.820 & 1.014 & 0.903 & 0.582 & 0.565 & 0.360 & 0.259 & 0.588 \\
\hline Noorabad & 0.200 & 0.379 & 0.663 & 0.647 & 0.711 & 1.193 & 1.143 & 1.354 & 1.373 & 1.550 & 0.686 & 0.292 & 0.955 \\
\hline Poldokhtar & 0.216 & 0.451 & 0.642 & 0.786 & 1.413 & 1.112 & 1.132 & 0.893 & 1.302 & 1.624 & 0.906 & 0.189 & 0.991 \\
\hline Ravansar & 0.197 & 0.197 & 0.262 & 0.360 & 0.526 & 1.215 & 1.987 & 1.799 & 1.210 & 0.943 & 0.461 & 0.204 & 0.995 \\
\hline Saghez & 0.176 & 0.154 & 0.258 & 0.407 & 0.665 & 1.198 & 1.314 & 1.100 & 0.778 & 0.471 & 0.255 & 0.123 & 0.707 \\
\hline Sanandaj & 0.195 & 0.162 & 0.267 & 0.505 & 0.715 & 1.223 & 1.180 & 1.195 & 0.890 & 0.375 & 0.254 & 0.184 & 0.724 \\
\hline Zarineh Obato & 0.227 & 0.263 & 0.395 & 0.532 & 0.843 & 1.081 & 0.992 & 1.261 & 1.482 & 1.137 & 0.469 & 0.290 & 0.857 \\
\hline
\end{tabular}


Table 4. The values of MBE between ET0-Harg and ET0-PM

\begin{tabular}{|c|c|c|c|c|c|c|c|c|c|c|c|c|c|}
\hline Station & JAN & FEB & MAR & APR & MAY & JUNE & JULY & AUG & SEP & OCT & NOV & $\mathrm{DEC}$ & Yearly \\
\hline Aleshtar & 0.112 & 0.022 & -0.077 & 0.298 & 0.470 & 0.785 & 0.618 & 0.657 & 0.093 & -0.272 & -0.048 & 0.080 & 0.228 \\
\hline Aligoodarz & -0.400 & -0.424 & -0.570 & -0.632 & -0.870 & -0.977 & -1.269 & -1.629 & -1.609 & -1.347 & -0.741 & -0.503 & -0.914 \\
\hline Azna & 0.042 & -0.114 & -0.070 & -0.072 & -0.042 & 0.376 & 0.264 & 0.264 & 0.140 & -0.426 & 0.002 & 0.002 & 0.031 \\
\hline Baneh & -0.335 & -0.407 & -0.933 & -1.232 & -1.680 & -2.820 & -2.563 & -3.072 & -3.015 & -2.103 & -0.938 & -0.507 & -1.634 \\
\hline Bijar & -0.273 & -0.402 & -0.636 & -0.989 & -1.155 & -1.295 & -1.001 & -1.262 & -1.567 & -1.268 & -0.737 & -0.419 & -0.917 \\
\hline Broujerd & -0.364 & -0.575 & -0.666 & -0.652 & -0.732 & -0.934 & -1.110 & -1.182 & -1.373 & -1.277 & -0.804 & -0.551 & -0.852 \\
\hline Dehloran & 0.001 & -0.158 & -0.190 & -0.224 & -0.114 & -0.540 & -0.294 & -0.170 & -0.395 & -0.356 & -0.270 & -0.017 & -0.227 \\
\hline Doroud & -0.302 & -0.767 & -0.950 & -0.845 & -0.863 & -0.482 & -0.220 & -0.382 & -0.467 & -1.333 & -0.637 & -0.467 & -0.643 \\
\hline Eslamabad Gharb & 0.205 & 0.247 & 0.333 & 0.626 & 0.821 & 0.946 & 1.066 & 0.616 & 0.401 & 0.426 & 0.307 & 0.231 & 0.519 \\
\hline Ghorveh & -0.216 & -0.329 & -0.574 & -0.793 & -0.826 & -0.883 & -0.615 & -0.949 & -1.154 & -1.006 & -0.496 & -0.307 & -0.679 \\
\hline Ilam & -0.165 & -0.279 & -0.387 & -0.462 & -0.807 & -1.150 & -1.265 & -1.217 & -1.138 & -0.776 & -0.402 & -0.147 & -0.683 \\
\hline Kangavar & 0.089 & 0.075 & 0.103 & 0.417 & 0.680 & 1.050 & 1.445 & 1.321 & 0.692 & 0.248 & 0.172 & 0.136 & 0.536 \\
\hline Kermanshah & 0.019 & -0.057 & 0.020 & 0.229 & 0.489 & 0.577 & 0.731 & 0.453 & 0.228 & -0.015 & -0.038 & 0.017 & 0.221 \\
\hline Khorramabad & 0.213 & 0.133 & 0.298 & 0.779 & 0.945 & 1.213 & 1.377 & 1.145 & 0.704 & 0.248 & 0.287 & 0.201 & 0.629 \\
\hline Kouhdasht & 0.173 & 0.095 & 0.258 & 0.593 & 0.836 & 1.315 & 1.471 & 1.546 & 1.065 & 0.279 & 0.266 & 0.243 & 0.678 \\
\hline Malayer & -0.182 & -0.298 & -0.317 & -0.303 & -0.149 & -0.048 & 0.038 & 0.011 & -0.510 & -0.564 & -0.341 & -0.280 & -0.245 \\
\hline Marivan & 0.153 & 0.141 & 0.168 & 0.360 & 0.540 & 0.650 & 0.871 & 0.895 & 0.131 & -0.033 & 0.119 & 0.096 & 0.341 \\
\hline Nahavand & -0.144 & -0.236 & -0.387 & -0.198 & 0.000 & 0.450 & 0.580 & 0.347 & 0.150 & -0.226 & -0.172 & -0.162 & 0.000 \\
\hline Noorabad & -0.182 & -0.318 & -0.624 & -0.598 & -0.670 & -1.118 & -0.958 & -1.210 & -1.302 & -1.466 & -0.666 & -0.286 & -0.783 \\
\hline Poldokhtar & -0.183 & -0.444 & -0.600 & -0.724 & -1.356 & -1.004 & -0.986 & -0.786 & -1.197 & -1.613 & -0.849 & -0.147 & -0.824 \\
\hline Ravansar & -0.072 & -0.135 & -0.131 & 0.031 & -0.175 & -1.007 & -1.819 & -1.666 & -1.093 & -0.788 & -0.315 & -0.013 & -0.598 \\
\hline Saghez & 0.059 & 0.025 & 0.107 & 0.246 & 0.528 & 0.956 & 0.978 & 0.733 & 0.305 & -0.055 & 0.045 & 0.026 & 0.329 \\
\hline Sanandaj & 0.083 & 0.023 & 0.080 & 0.359 & 0.567 & 0.916 & 0.863 & 0.928 & 0.622 & 0.166 & 0.107 & 0.048 & 0.397 \\
\hline Zarineh Obato & -0.183 & -0.221 & -0.311 & -0.471 & -0.670 & -0.854 & -0.684 & -0.995 & -1.368 & -0.990 & -0.413 & -0.249 & -0.618 \\
\hline
\end{tabular}

Table 5 . The monthly $\mathrm{C}$ values for different months for investigated stations

\begin{tabular}{|c|c|c|c|c|c|c|c|c|c|c|c|c|c|}
\hline Station & JAN & FEB & MAR & APR & MAY & JUNE & JULY & AUG & SEP & OCT & NOV & $\mathrm{DEC}$ & Yearly \\
\hline Aleshtar & 0.0021 & 0.0023 & 0.0024 & 0.0021 & 0.0021 & 0.0020 & 0.0021 & 0.0021 & 0.0023 & 0.0025 & 0.0024 & 0.0022 & 0.0021 \\
\hline Aligoodarz & 0.0033 & 0.0030 & 0.0029 & 0.0027 & 0.0027 & 0.0027 & 0.0027 & 0.0029 & 0.0031 & 0.0034 & 0.0034 & 0.0034 & 0.0028 \\
\hline Azna & 0.0022 & 0.0025 & 0.0024 & 0.0023 & 0.0023 & 0.0022 & 0.0022 & 0.0022 & 0.0022 & 0.0026 & 0.0023 & 0.0022 & 0.0023 \\
\hline Baneh & 0.0033 & 0.0032 & 0.0034 & 0.0033 & 0.0032 & 0.0035 & 0.0033 & 0.0035 & 0.0039 & 0.0042 & 0.0040 & 0.0038 & 0.0035 \\
\hline Bijar & 0.0033 & 0.0034 & 0.0032 & 0.0031 & 0.0029 & 0.0028 & 0.0027 & 0.0028 & 0.0032 & 0.0035 & 0.0037 & 0.0036 & 0.0029 \\
\hline Broujerd & 0.0031 & 0.0032 & 0.0030 & 0.0027 & 0.0026 & 0.0026 & 0.0027 & 0.0027 & 0.0029 & 0.0032 & 0.0034 & 0.0035 & 0.0027 \\
\hline Dehloran & 0.0023 & 0.0025 & 0.0024 & 0.0024 & 0.0023 & 0.0024 & 0.0024 & 0.0023 & 0.0024 & 0.0025 & 0.0025 & 0.0023 & 0.0024 \\
\hline Doroud & 0.0030 & 0.0034 & 0.0031 & 0.0028 & 0.0027 & 0.0025 & 0.0024 & 0.0024 & 0.0025 & 0.0032 & 0.0032 & 0.0033 & 0.0026 \\
\hline Eslamabad Gharb & 0.0019 & 0.0019 & 0.0020 & 0.0019 & 0.0020 & 0.0020 & 0.0020 & 0.0021 & 0.0021 & 0.0020 & 0.0020 & 0.0018 & 0.0020 \\
\hline Ghorveh & 0.0030 & 0.0030 & 0.0030 & 0.0029 & 0.0028 & 0.0027 & 0.0025 & 0.0027 & 0.0029 & 0.0032 & 0.0032 & 0.0031 & 0.0027 \\
\hline Ilam & 0.0026 & 0.0027 & 0.0027 & 0.0026 & 0.0027 & 0.0027 & 0.0027 & 0.0028 & 0.0028 & 0.0029 & 0.0028 & 0.0026 & 0.0027 \\
\hline Kangavar & 0.0021 & 0.0022 & 0.0022 & 0.0020 & 0.0020 & 0.0020 & 0.0019 & 0.0019 & 0.0020 & 0.0021 & 0.0021 & 0.0020 & 0.0020 \\
\hline Kermanshah & 0.0022 & 0.0024 & 0.0023 & 0.0022 & 0.0021 & 0.0021 & 0.0021 & 0.0022 & 0.0022 & 0.0023 & 0.0023 & 0.0023 & 0.0022 \\
\hline Khorramabad & 0.0019 & 0.0021 & 0.0021 & 0.0019 & 0.0019 & 0.0019 & 0.0019 & 0.0019 & 0.0020 & 0.0021 & 0.0020 & 0.0019 & 0.0020 \\
\hline Kouhdasht & 0.0020 & 0.0022 & 0.0021 & 0.0020 & 0.0020 & 0.0019 & 0.0019 & 0.0018 & 0.0019 & 0.0021 & 0.0020 & 0.0019 & 0.0019 \\
\hline Malayer & 0.0027 & 0.0028 & 0.0026 & 0.0025 & 0.0024 & 0.0023 & 0.0023 & 0.0023 & 0.0025 & 0.0027 & 0.0028 & 0.0028 & 0.0024 \\
\hline Marivan & 0.0020 & 0.0021 & 0.0021 & 0.0021 & 0.0021 & 0.0021 & 0.0020 & 0.0020 & 0.0022 & 0.0023 & 0.0021 & 0.0021 & 0.0021 \\
\hline Nahavand & 0.0026 & 0.0027 & 0.0027 & 0.0024 & 0.0023 & 0.0021 & 0.0021 & 0.0022 & 0.0022 & 0.0025 & 0.0025 & 0.0026 & 0.0022 \\
\hline Noorabad & 0.0028 & 0.0029 & 0.0029 & 0.0027 & 0.0026 & 0.0027 & 0.0026 & 0.0027 & 0.0029 & 0.0034 & 0.0033 & 0.0030 & 0.0028 \\
\hline Poldokhtar & 0.0026 & 0.0028 & 0.0027 & 0.0027 & 0.0028 & 0.0026 & 0.0026 & 0.0025 & 0.0028 & 0.0033 & 0.0032 & 0.0025 & 0.0027 \\
\hline Ravansar & 0.0024 & 0.0025 & 0.0024 & 0.0023 & 0.0024 & 0.0026 & 0.0029 & 0.0029 & 0.0028 & 0.0029 & 0.0027 & 0.0023 & 0.0027 \\
\hline Saghez & 0.0021 & 0.0022 & 0.0022 & 0.0021 & 0.0021 & 0.0020 & 0.0020 & 0.0020 & 0.0021 & 0.0023 & 0.0022 & 0.0022 & 0.0021 \\
\hline Sanandaj & 0.0021 & 0.0023 & 0.0022 & 0.0021 & 0.0021 & 0.0020 & 0.0020 & 0.0020 & 0.0020 & 0.0022 & 0.0022 & 0.0022 & 0.0020 \\
\hline Zarineh Obato & 0.0030 & 0.0029 & 0.0028 & 0.0027 & 0.0027 & 0.0027 & 0.0026 & 0.0027 & 0.0031 & 0.0033 & 0.0032 & 0.0032 & 0.0027 \\
\hline
\end{tabular}


Table 6. The R values (ratio between ET0-Harg and ET0-PM)

\begin{tabular}{|c|c|c|c|c|c|c|c|c|c|c|c|c|c|}
\hline Station & JAN & FEB & MAR & APR & MAY & JUNE & JULY & AUG & SEP & OCT & NOV & DEC & Yearly \\
\hline Aleshtar & .101 & .013 & 0.974 & 1.080 & 1.093 & 1.123 & 1.086 & 1.100 & 1.017 & 0.929 & 0.975 & 1.068 & 1.058 \\
\hline Aligoodarz & .701 & 0.758 & 0.789 & .843 & 0.844 & 0.865 & 0.840 & 0.790 & 0.747 & 0.684 & 0.686 & 0.677 & 0.792 \\
\hline Azna & 1.047 & 0.927 & 0.974 & 0.980 & 0.992 & 1.059 & 1.038 & 1.041 & 1.027 & 0.886 & 1.001 & 1.002 & 1.008 \\
\hline Baneh & 0.694 & 0.723 & 0.679 & 0.708 & 0.717 & 0.665 & 0.707 & 0.651 & 0.583 & 0.549 & 0.571 & 0.609 & 0.656 \\
\hline Bijar & 0.686 & 0.694 & 0.732 & 0.754 & 0.785 & 0.815 & 0.863 & 0.821 & 0.729 & 0.657 & 0.623 & 0.638 & .770 \\
\hline Broujerd & 0.736 & 0.722 & 0.780 & 0.848 & 0.875 & 0.877 & 0.866 & 0.849 & 0.786 & 0.709 & 0.673 & 0.666 & 0.815 \\
\hline Dehloran & 1.001 & 0.934 & 0.946 & 0.958 & 0.983 & 0.938 & 0.966 & 0.979 & 0.939 & 0.919 & 0.897 & 0.990 & 0.955 \\
\hline Doroud & 0.775 & 0.673 & 0.733 & 0.814 & 0.856 & 0.933 & 0.970 & 0.945 & 0.917 & 0.706 & 0.724 & 0.699 & 0.855 \\
\hline Eslamabad Gharb & 1.224 & 1.182 & 1.149 & 1.185 & 1.172 & 1.143 & 1.160 & 1.094 & 1.079 & 1.132 & 1.194 & 1.235 & 1.144 \\
\hline & 0.770 & 0.770 & 0.772 & & & & & & 0.789 & & & 0.740 & 0.825 \\
\hline Ilam & 0.876 & 0.851 & 0.861 & 0.886 & 0.862 & 0.8 & 0.837 & 0.834 & 0.806 & 0.798 & 0.814 & 0.893 & 0.841 \\
\hline Kangavar & 1.097 & 1.051 & 1.042 & 1.120 & 1.144 & 1.174 & 1.231 & 1.226 & 1.147 & 1.080 & 1.106 & 1.127 & 1.155 \\
\hline Kermanshah & 1.016 & 0.966 & 1.008 & 1.060 & 1.095 & 1.084 & 1.100 & 1.065 & 1.042 & 0.996 & 0.981 & 1.014 & 1.056 \\
\hline Khorramabad & 1.188 & 1.076 & 1.119 & 1.221 & 1.189 & 1.187 & 1.203 & 1.178 & 1.136 & 1.072 & 1.153 & 1.164 & 1.166 \\
\hline Kouhdasht & 1.153 & 1.053 & 1.096 & 1.158 & 1.157 & 1.201 & 1.219 & 1.252 & 1.218 & 1.078 & 1.148 & 1.203 & 1.179 \\
\hline & & & & & & & & & 0.907 & 0.846 & & .826 & 0.939 \\
\hline Marivan & 1.155 & 1.100 & 1.075 & & & & & & 1.026 & 0.991 & 1.071 & 1.092 & 1.096 \\
\hline Nahavand & 0.877 & 0.867 & 0.864 & 0.950 & & 1.073 & 1.089 & 1.056 & 1.031 & 0.934 & 0.906 & 0.876 & 1.000 \\
\hline Noorabad & 0.835 & 0.802 & 0.792 & 0.847 & 0.875 & 0.848 & 0.876 & 0.839 & 0.788 & 0.675 & 0.695 & 0.775 & 0.818 \\
\hline Poldokhtar & 0.887 & 0.824 & 0.842 & 0.864 & 0.823 & 0.885 & 0.889 & 0.905 & 0.833 & 0.707 & 0.714 & 0.906 & 0.846 \\
\hline Ravansar & 0.936 & 0.914 & 0.948 & 1.009 & 0.967 & 0.870 & 0.796 & 0.800 & 0.824 & 0.801 & 0.843 & 0.988 & 0.863 \\
\hline Saghez & 1.079 & 1.023 & 1.055 & 1.075 & 1.121 & 1.171 & 1.159 & 1.125 & 1.066 & 0.982 & 1.031 & 1.030 & 1.101 \\
\hline Sanandaj & 1.090 & 1.015 & 1.034 & 1.100 & 1.117 & 1.147 & 1.127 & 1.144 & 1.130 & 1.054 & 1.064 & 1.045 & 1.110 \\
\hline Zarineh Obato & 0.765 & 0.787 & 0.824 & 0.852 & 0.852 & 0.861 & 0.897 & 0.848 & 0.746 & 0.702 & 0.731 & 0.730 & 0.823 \\
\hline
\end{tabular}

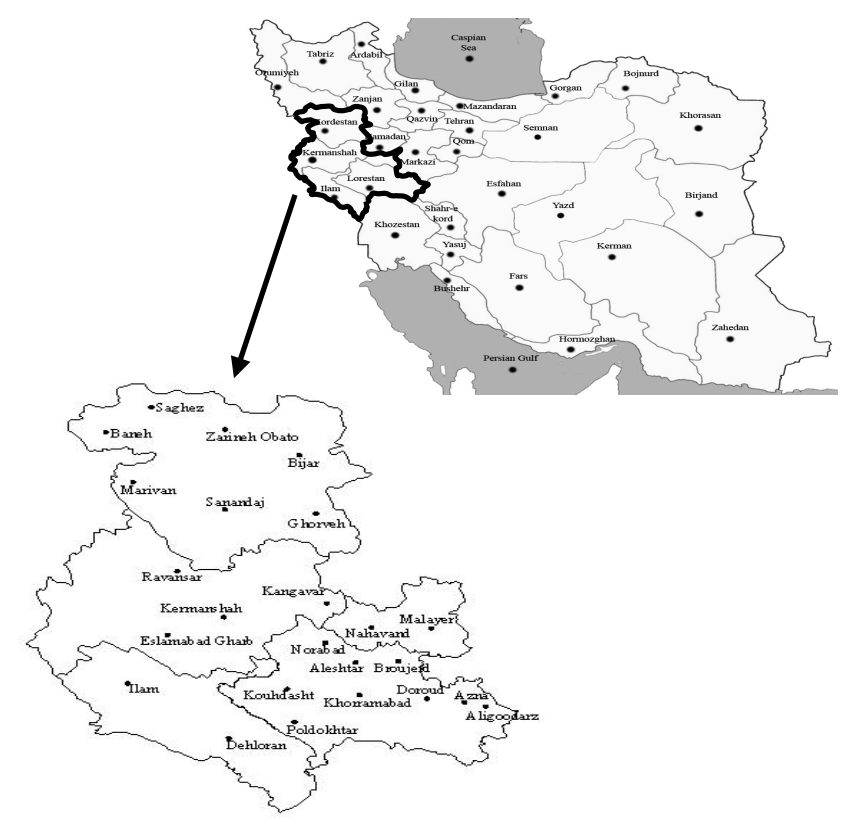

Figure 1. Spatial distribution of the 24 meteorological stations used in the study 


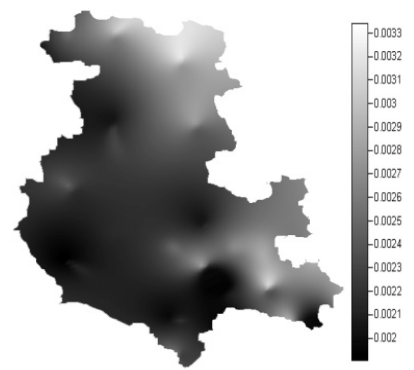

January

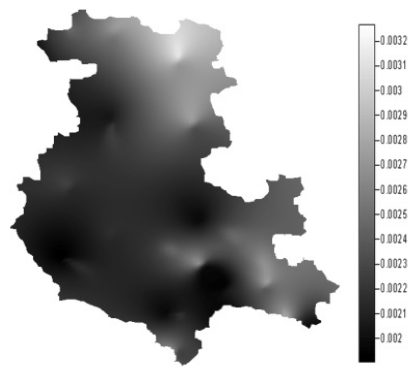

April

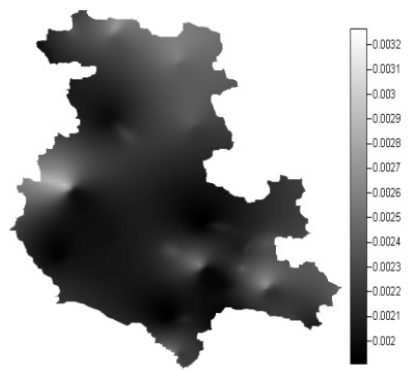

July

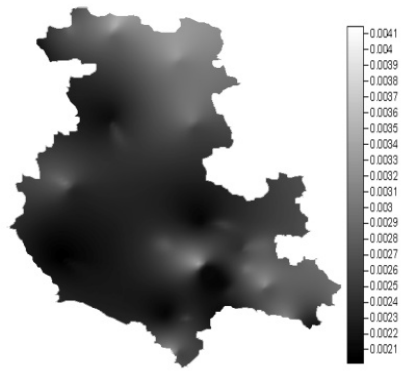

October

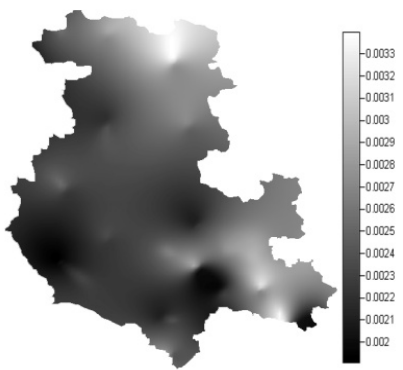

February

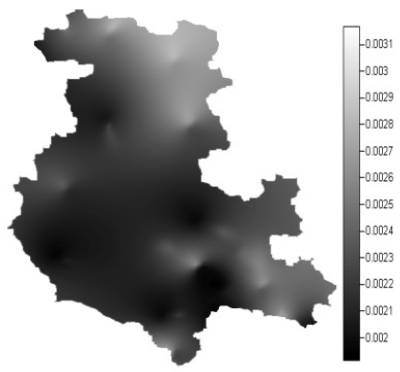

May

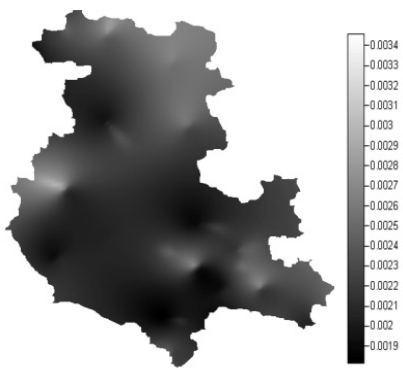

August

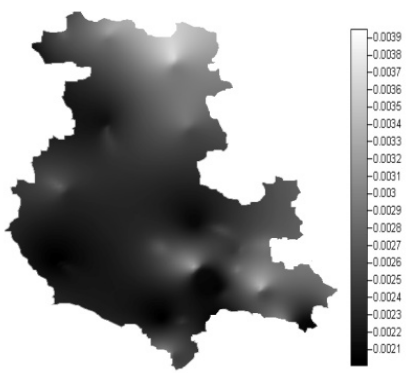

November

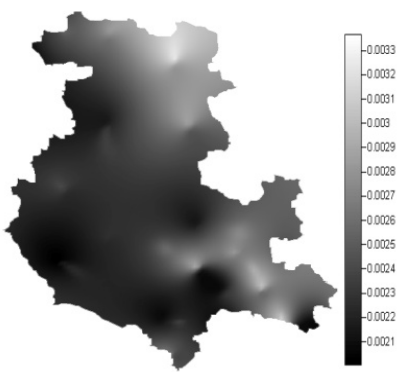

March

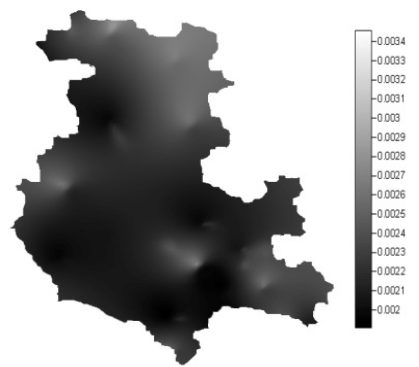

June

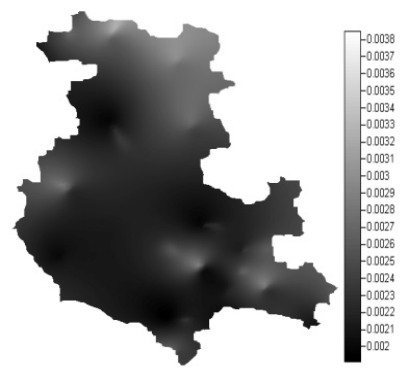

Septembe

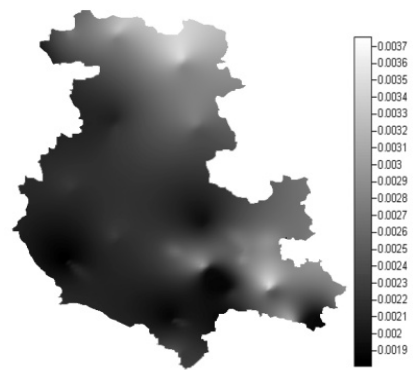

December

Figure 2. Place distribution of $\mathrm{C}$ coefficient based of monthly scale 


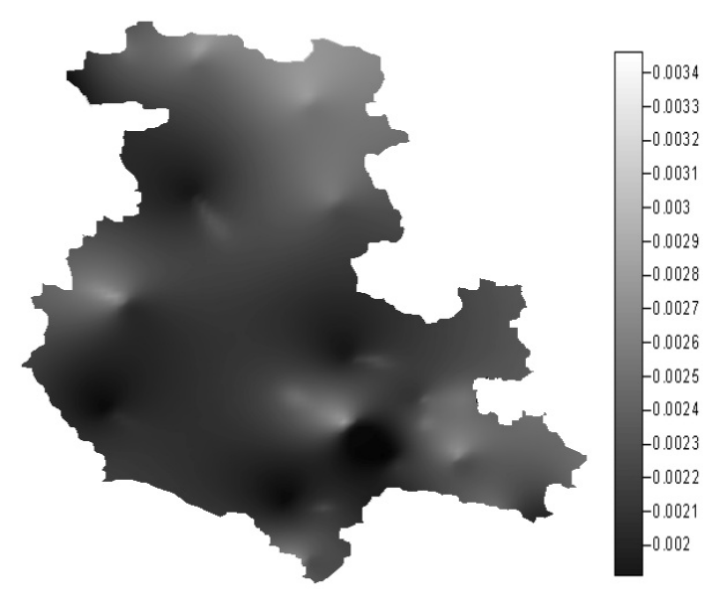

Figure 3. Place distribution of $\mathrm{C}$ coefficient based of yearly scale

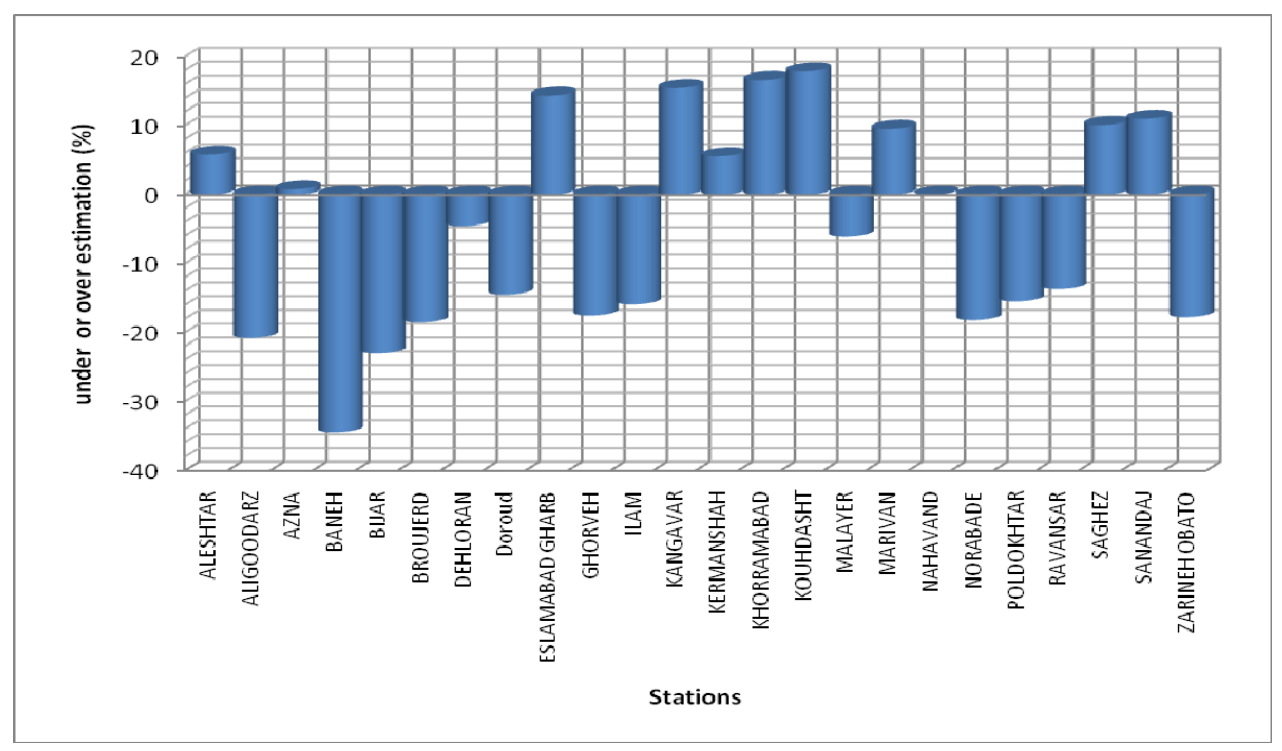

Figure 4. The percentage of under or over ETo estimation on yearly scale

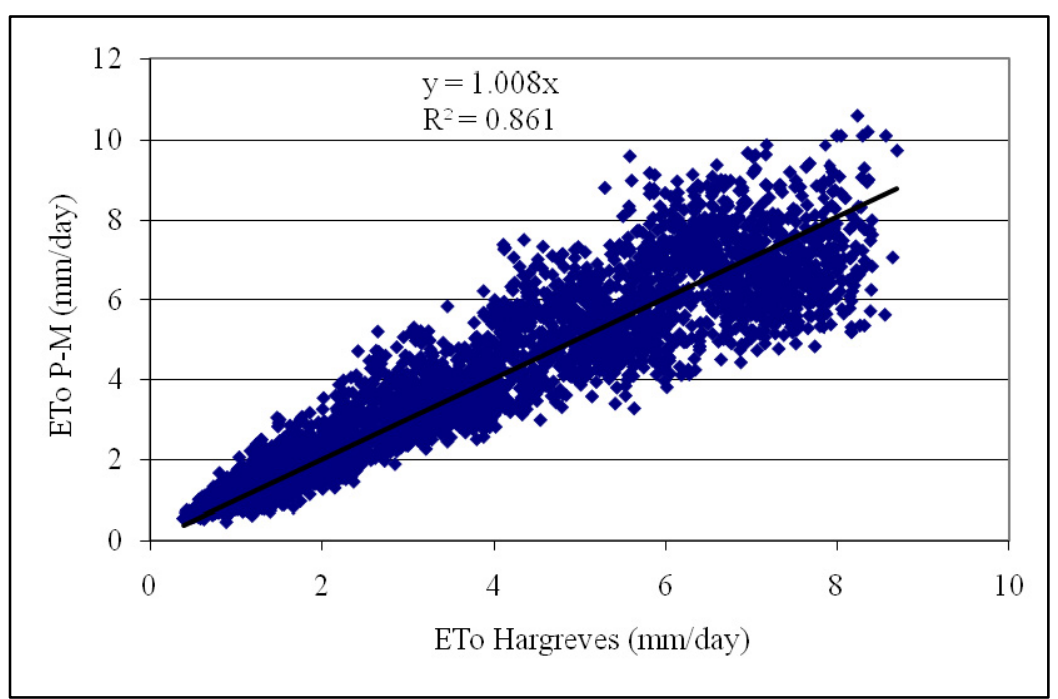

Figure 5. Regression models of ETo estimations by PM vs Harg for different meteorological stations 